\title{
Educational Platforms and Learning Approaches in University Education
}

\author{
Ana I. Vázquez-Martínez ${ }^{1} \&$ Juan M. Alducin-Ochoa ${ }^{1}$ \\ ${ }^{1}$ Superior Technical School of Construction Engineering, Seville University, Seville, Spain \\ Correspondence: Ana I. Vázquez-Martínez, Escuela Técnica Superior de Ingeniería de Edificación, Avda. Reina \\ Mercedes, no 4a, 41012, Seville, Spain. Tel: 34-9-5455-6611. E-mail: aisabel@us.es
}

Received: October 8, 2013 Accepted: January 22, 2014 Online Published: March 31, 2014

doi:10.5539/ass.v10n7p1

URL: http://dx.doi.org/10.5539/ass.v10n7p1

\begin{abstract}
This study was conducted at the Superior Technical School of Construction Engineering of Seville (Spain) with students registered in the Materials I course who received academic training using blended learning methodology. Technical degree programs are characterized by a high dropout rate and academic underachievement. For that reason, the study aimed to assess the dominant learning approaches among these students, the relationship between leaning approaches and academic achievement, the relationship between learning approaches and the extent of WebCT platform use, and the influence of learning approaches on the students' assessment of the platform. To identify students' learning approaches, the R-SPQ-2F questionnaire developed by Biggs, Kember, and Leung (2001) was used. The students assessed the WebCT platform using an ad hoc PSEW questionnaire. The study was descriptive and used a correlational design. The study was conducted retroactively and measured variables that were not experimentally manipulated. The results indicate that the majority of the students have a low-intensity deep approach. The deep approach was more common among the female students than the male students, and the female students obtained higher scores on the deep motivation and deep strategy subscales. The dominant learning approach had no influence on academic achievement, but the dominant learning approach did influence the extent of WebCT platform use, as well as the students' assessments of the platform.
\end{abstract}

Keywords: learning approach, engineering, university, blended learning

\section{Introduction}

This article addresses two very important issues for university education: the use of online educational platforms and students' learning approaches.

Spanish universities are increasingly investing resources in educational platforms to support classroom teaching and to improve teaching and learning processes. The University of Seville used the WebCT platform in 2006-2007 to implement a blending learning model. This model is increasingly common in university settings (Ellis, Ginns, \& Piggot, 2009; Mackenzie \& Wolsh, 2009) and involves complementary face-to-face and online teaching methods (Mitchell \& Forer, 2010). This strategy allows teachers to take advantage of the best aspects of each method (Harding, Kaczynski, \& Wood, 2005; Osguthorpe \& Graham, 2003), as long as the overall design is educationally sound (Precel, Eshet-Alkalai \& Alberton, 2009).

When combining these two methods, it is necessary to understand how students perceive and evaluate the combined methodology because their perceptions will influence their learning approaches (Diseth, 2007; Ramsden, 2002). In addition, even though the combined methodology produces the expected academic results, Ellis et al. (2009) indicate that the current research is insufficient to determine whether the use of communications and information technology (CIT) in classroom teaching improves learning outcomes.

However, the study of learning approaches has increasingly become an area of interest because knowledge about individual differences can help to develop more effective teaching-learning models (Scott, 2010) that are higher in quality (Halawi, McCarthy, \& Moughalu, 2009; Biggs, Kember, \& Leung, 2001) and that allow students to reach their goals (Oskay, Erdem, Akkoyunlu \& Yilmaz, 2010; Biggs, 2005). Inadequate classroom practices, however, can impede the learning process (Lashley \& Barron, 2006) because students' perceptions of coursework are closely related to their coping mechanisms (Ginns \& Ellis, 2009). Diagnosing learning approaches thus becomes more and more important to enable teachers to assist students in a more suitable and individualized manner.

Within the fields of architecture and engineering, research that combines both topics is rare, though studies 
published by Vázquez-Martínez (2011), Carrascal, Alvarino and Díaz (2009), and Ellis, Goodyear, Calvo and Prosser (2008) have done so. This field is characterized by a high dropout rate and low academic achievement (Godfrey, Aubrey, \& King, 2010; French, Immekus, \& Oakes, 2005).

This research was conducted at the Superior Technical School of Construction Engineering of Sevilla (Spain) with students registered in the Materials I course. The participating students received four weekly hours of teaching in a traditional classroom in addition to the WebCT platform, which contained materials such as the syllabus (in an HTML format), complementary readings, quizzes, and both synchronous and asynchronous communication tools. In this design, the students must interact with the content, the teacher, the other students, and the available resources. It has been established that greater interaction with the materials facilitates greater knowledge gains (Sabry \& Balwuin, 2003). The course design was based on a follow-up with the students and the overall assessments of the learning process by the students. Thus, the evaluation process was formative and informative, not based entirely on traditional exams, which favor a shallow approach (Scouller, 1998). Discussion forums were also designed to encourage reflective processes to improve analytical and summarizing skills and to push the students toward a deeper approach to learning.

The following questions guided this study:

1) What is the distribution of the dominant learning approaches used by the participating students?

2) Does the dominant learning approach affect academic achievement?

3 ) Is there a relationship between the learning approach and the extent of WebCT platform use?

4) Does the learning approach affect the overall assessment of WebCT?

\subsection{Learning Approach}

According to Biggs (1987, p. 85), learning approaches are "learning processes that emerge from students' perceptions of academic work, and are influenced by their personal characteristics." Although each individual has a preferred approach, this approach can be enhanced by or inhibited by certain learning environments (Biggs, 1987). Therefore, Biggs et al. (2001, p. 137) state that a "learning approach describes the nature of the relationship between student, context, and work," and there is a moderate relationship between academic achievement and learning approaches (Biggs et al., 2001).

The learning approach concept includes the student's intent to complete a task and the processes used to reach this goal. The learning approach also depends on the student's previous learning experiences (Entwistle, 1988).

Learning approaches are influenced by certain individual characteristics, such as age, gender, previous experience, and personality, which determine the student's orientation toward learning and the learning context. The orientation toward learning and the learning context determine students' perceptions of assigned tasks, which are a key component of the learning approach (Duff, Boyle, Dunleavy, \& Ferguson, 2004).

\subsubsection{Shallow Approach and Deep Approach}

The surface and deep approaches were identified by Marton and Säljo (1976), who studied the strategies students use to complete assigned work and discovered two levels of information processing for which the two approaches are named. In that study, the students with the deep approach were interested in understanding the meaning of the material provided (Boekaerts, 1996), whereas those who used a shallow approach were only interested in memorizing the content so that they would later be able to respond to the questions that they would be asked (Kember \& Harper, 1987). With respect to academic results, each approach is composed of two elements: motive and strategy. Motive refers to why the student commits to a task, and strategy described how they do it, including the means they have to complete it.

With respect to academic achievement, the students with a shallow approach obtain the weakest results (Lingard, Minasian-Batmanian, Vella, Cathers, \& Gonzalez, 2009; Ellis et al., 2008; Ellis, Taylor, \& Drury, 2007; Trigwell \& Ashwin, 2006; Biggs, 1987; Watkins, 1983). Other authors have argued that the type of approach is independent from academic achievement (Ramsden, Martin, \& Bowden, 1989). However, it would be ideal if the students' dominant approach was the deep approach, which would allow them to develop all of their learning potential (Laird, Shoup, \& Kuh, 2005).

To summarize, the characteristics of each approach are as follows:

- Deep approach: these students are interested in academic tasks and enjoy them, seek the inherent meaning of the task, personalize the task and connect it to their personal experience and the real world, integrate the different parts of a task into a whole, relate the entire task to previous knowledge, and try to develop theories and 
hypotheses (Biggs, 1987, 2005). These students view work as an opportunity to increase their knowledge and relate new content to previous knowledge (Marton \& Säljo, 2005; Lucas, 2001). The deep approach is related to higher order processing and thinking (Akyol \& Garrison, 2011; Biggs, 2003). Carrying out extensive information searches (Heinström, 2006), these students are intrinsically motivated (Spencer, 2003), and they evaluate the logic of their arguments (Prosser \& Trigwell, 1999). These students spend more time studying and find the material easy to understand (Svensson, 1977).

- Surface approach: these students perceive academic tasks as an obligation or an imposition that will allow them to achieve some goal. They see the different parts of a task as different elements with no relationship between them or to any other work. They avoid searching for any personal meaning in the task, worry about the time it will take them to complete the task, and focus on memorization and reproduction of superficial aspects of the task (Biggs, 1987, 2005). These students associate various elements without reflection or understanding, and they see academic tasks as external impositions (Marton \& Säljo, 2005). They want a passing grade with minimal effort (Biggs, 2005; Entwistle, 2005; Heinström, 2006; Lucas, 2001), they suffer from high anxiety about their coursework (Biggs, 2005), they find assignments burdensome and unpleasant, and they tend to fail tests (Svensson, 1977). This approach is directly related to traditional evaluation systems and to extrinsic motivations (Hall, Ramsay, \& Raven, 2004).

\subsection{Blended Learning}

Blended learning has been defined as a teaching method that combines the best elements of both face-to-face and distance learning (Bersin, 2004; Garrison \& Vaughan, 2008; Heinze \& Procter, 2006; Heterick \& Twigg, 2003; Klein, Noe, \& Wang, 2006). This teaching method emphasizes interactivity amongst the participants and between participants and available resources. It is designed to promote autonomous and self-controlled learning (Meurant, 2010; Vázquez-Martínez \& Alducin-Ochoa, 2008) through the students' active, retro-active and reflexive participation.

Students acquire the skills taught in their courses through the use of technology. The content of blended learning courses should therefore be presented in a sequenced and structured way that supports the learning objectives. The courses should also be rich in resources that efficiently support knowledge management and the teaching-learning process (related articles, video clips, web sites, e-activities, knowledge assessment tests, etc.). The courses should also employ asynchronous and synchronous communication tools and be sufficiently flexible to adapt to the learning rhythm of each student and his or her learning focus and style.

It should be noted that a student's ability to effectively use blended learning technology does not necessarily give them control over the teaching-learning process. Though technology does result in a control shift from the teacher to the student, this does not necessarily imply that the student has greater control over his or her own learning experience. The student does, however, already have the cognitive and metacognitive skills necessary to convert a technological background into a learning background.

Some of the positive characteristics of blended learning are its physical delocalization and its use of new contexts for communication and learning.

Several authors (Ally, 2004; Driscoll, 2002; Klein et al., 2006) suggest that one of the main characteristics of distance learning is that the teacher and the student are separated by time and distance but united through media. This physical separation can be conducive to new educational possibilities by flexibly meeting the needs of the users; allowing continuous training; adapting to space, time and learning rhythms; and favoring equality of opportunity. Although students using the blended learning format must attend programmed, face-to-face classes, the design of and available resources on the platform increase the academic flexibility (Cheng \& Tsai, 2012; Davidson, 2011; Neto, Vieira, Moreira, \& Ribeiro, 2013; Stricker, Weible, \& Bissmath, 2011).

While face-to-face teaching requires students and teachers to be present in the classroom and to engage in strictly synchronous communication processes, educational platforms offer the possibility of synchronous and asynchronous communication. This increases the flexibility of communicative processes and increases educational possibilities (Basset, 2011; Ching \& Hsu, 2011; Neumann, Neumann, \& Hood, 2011). The student can participate at any time and place and be part of a learning community. Asynchronous tools also give the student time to think and to evaluate the answer he or she will give. Two important consequences of using such tools are reflection and creativity (Shannon, Francis, Leng Chooi, \& Ling, 2012; Mosca, Ball, Buzza, \& Paul, 2010). This allows learners to construct, deconstruct and reconstruct knowledge in a collective process. According to MacGregor (2001), the greater the social interaction, the better the quality of learning.

A virtual learning community should include active interaction, collaborative learning, social construction of 
meaning, sharing of resources and exchange of support messages among students (Paloff \& Pratt, 1999). Garrison, Anderson and Archer (2000) define social presence as the capacity of students to project socially and emotionally in a research community. For Arbaugh (2004), social presence comprises three components: emotional (expressions of emotion, feelings and mood), interactive (behaviors that indicate that the students follow the thread of a discussion, express gratitude, complement what has been taught) and cohesive (students address others by their names, include their signature at the end of messages). The main conditioning factors in the communicative processes are the tutor's answers, feedback and the tone of the messages (Russo \& Campbell, 2004).

Promoting new learning scenarios acquires special relevance in blended learning courses (Cooner, 2010; De Witt \& Kerr, 2003). In face-to-face learning, the information to be transformed into knowledge by the student is transmitted by the teacher. Through learning platforms, the student can access all the available information, and he or she selects which information he or she wants to use. Therefore, it is essential to develop a wide and diverse offering of high-quality resources. The student in a flexible learning environment is engaged in an independent and autonomous learning process, constructs his or her own knowledge and manages his or her own time. The teacher is the learning counsellor who accompanies the student and follows up on the student's work using the tools available on the platforms (Vázquez-Martínez, 2011).

\section{Methods}

\subsection{Design}

Our research questions aim to analyze the distribution of learning approaches among students and the relationship between learning approaches and other variables (achievement, the extent to which educational tools are used, and the assessment of an online platform). A correlational study design was used. The study was descriptive and retroactive, aimed to identify correlations, and measured variables that were not experimentally manipulated.

\subsection{Participants}

The population comprises one hundred seventy-six students, all of whom participated in the study and completed the R-SPQ-2F questionnaire at the beginning of the course. Of these participants, 60 (34.09\%) were female and $116(65.91 \%)$ were male. There were $110(62.50 \%)$ students between $18-20$ years of age, $40(22.73 \%)$ between 21-25 years of age, 17 (9.66\%) between 26-30 years of age, and 9 (5.11\%) over 30 years of age, with an average age of 21.25 years. Grades were available for all of them, but only 116 completed the WebCT (PSEW) perceptions and satisfaction questionnaire at the end of the course.

\subsection{Instruments}

The Revised Two-Factor Study Process Questionnaire (R-SPQ-2F) by Biggs et al. (2001), adapted by Recio (2007) for the Spanish context, was used. The questionnaire consists of 20 items measured on a Likert scale (from 1 to 5).

To determine the dominant learning approach (the approach with a higher score), a score was determined for each approach for each student using both the main scale and the subscale. The points for the corresponding items were tallied (Biggs et al., 2001):

Deep Approach: DA=DM+SM

DM- Deep Motive: $1+5+9+13+17$

DS- Deep Strategy: $2+6+10+14+18$

Shallow Approach: $\mathrm{SA}=\mathrm{SM}+\mathrm{SS}$

SM- Surface Motive: $3+7+11+15+19$

SS- Surface Approach: 4+8+12+16+20

To categorize the intensity of the approach, the difference between a student's deep approach score and surface approach score was calculated and assigned a rating using the following classification system recommended by Recio (2007):

- 1 to 13 points: low;

- 14 to 26 points: medium;

- 27 to 40 points: high.

To determine the reliability of the R-SPQ-2F questionnaire, Cronbach's alpha coefficients were calculated 
( $\alpha=.680$ for the deep approach items and $\alpha=.739$ for the surface scale items) and indicated an acceptable level of reliability (George \& Mallery, 1995). Biggs et al. (2001) obtained $\alpha=.73$ for the deep approach and $\alpha=.64$ for the surface approach.

Use data for the WebCT platform were obtained using the "follow-up" option on the platform itself. The global assessment data were obtained using the WebCT (PSEW) perceptions and satisfaction questionnaire designed for this purpose, which consisted of two parts. The first part collected data on the student's perceptions in three areas: content (16 items), formal and technical aspects ( 8 items), and quizzes, self-tests, and final tests (12 items). On the second part of the questionnaire, the students were asked to assess various aspects of the course, such as the organization of course elements, the use of the forums, e-mail, self-assessments, the ease of use, theoretical content, practical content, announcements, and the participation of the professors. For all of those factors, the items were assessed on a five-point Likert scale ranging from "strongly disagree" to "strongly agree." This questionnaire produced a Cronbach's alpha coefficient of .923, which implies an excellent level of reliability (George \& Mallery, 1995).

\subsection{Data Analysis}

SPSS version 17 was used for the data analysis. To answer the first research question, descriptive methods were used to assess the correlation (i.e., the contingency coefficient and the Chi-squared test $\left(\chi^{2}\right)$ ). To analyze the rest of the research questions, parametric tests were used when the dependent variable was measured at the interval level and had a normal distribution. The Student's t-test was used if the independent variable was dichotomous, and an analysis of variance (ANOVA) was conducted if the independent variable was polytomous. Nonparametric tests were used if the dependent variable was not measured at the interval level or did not have a normal distribution. Specifically, the Mann-Whitney U-test was used if the independent variable was dichotomous, and the Kruskal-Wallis test was used if the independent variable was polytomous. A confidence level of $95 \%$ was established for all of the tests $(\alpha=.05)$.

\section{Resultses}

\subsection{Dominant Learning Approaches among the Students}

Students were assigned to a dominant learning approach category according to their scores on the main scale, and the following distribution was observed (Table 1):

Table 1. Distribution of dominant learning approaches

\begin{tabular}{lccccccccccc}
\hline & & \multicolumn{1}{c}{} & \multicolumn{9}{c}{ Intensity of approach } \\
& & \multicolumn{1}{c}{ High } & \multicolumn{3}{c}{ Medium } & \multicolumn{3}{c}{ Low } \\
Approach & $\mathrm{f}$ & $\%$ & Male & Female & Total & Male & Female & Total & Male & Female & Total \\
\hline Deep & 139 & 78.98 & 1 & 1 & 2 & 25 & 17 & 42 & 58 & 37 & 95 \\
Surface & 30 & 17.04 & 0 & 0 & 0 & 3 & 0 & 3 & 23 & 4 & 27 \\
Undefined & 7 & 3.98 & & & & & & & & & \\
\hline
\end{tabular}

Most of the students were in the deep approach group ( $\mathrm{f}=139,78.98 \%$ ) rather than the shallow group ( $\mathrm{f}=30$, $17.04 \%)$. There were seven students (3.98\%) with the same score for both approaches, and therefore, they did not fall into either category. With respect to intensity, a low level of intensity was found in both groups.

As shown in Figure 1, a greater percentage of female students (91.67\%) than male students (72.41\%) fall into the deep approach category, whereas a greater percentage of male students $(22.41 \%)$ than female students $(6.67 \%)$ fall into the shallow approach category. This difference was statistically significant $\left(\chi^{2}(2, N=176)=8.831\right.$, $p=.012$ ), although when the contingency coefficient (.219) is taken into account, the size of the effect is lower than the medium level of .30 .

The statistics for the scores obtained on the main scale for deep and shallow approaches are detailed in Table 2 . 
Table 2. Statistics for scores obtained from both learning approaches

\begin{tabular}{lcc}
\hline Statistic & Deep approach (DA) & Surface approach (SA) \\
\hline Minimum & 19 & 12 \\
Maximum & 44 & 47 \\
Mean & 31.05 & 23.58 \\
Median & 30.50 & 23.00 \\
Std. Deviation & 4.877 & 5.838 \\
Skewness & .283 & .784 \\
Std. error of skewness & .183 & .183 \\
Kurtosis & -.105 & 1.142 \\
Std. error of kurtosis & .364 & .364 \\
Mean for females & 31.58 & 21.35 \\
Mean for males & 30.78 & 24.73 \\
\hline
\end{tabular}

The mean deep approach score among the women $(M=31.58)$ was higher than the mean for men $(M=30.78)$, whereas the mean shallow approach score for women $(M=21.35)$ was lower than the mean among the men $(M=24.73)$.

Finally, the score obtained by each student on each category of the subscale was calculated (Table 3). One student obtained the same score on both scales and therefore was not assigned to any category.

Table 3. Distribution of dominant learning approaches by subscales

\begin{tabular}{lcccccccc}
\hline & \multicolumn{4}{c}{ Deep } & \multicolumn{5}{c}{ Superficial } \\
Subscale & Male & Female & Total & $\%$ & Male & Female & Total & $\%$ \\
\hline Motive & 59 & 42 & 101 & $71.13 \%$ & 12 & 1 & 13 & $39.39 \%$ \\
Strategy & 17 & 6 & 23 & $16.20 \%$ & 15 & 4 & 19 & $57.58 \%$ \\
Both $^{\text {a }}$ & 11 & 7 & 18 & $12.68 \%$ & 1 & 0 & 1 & $3.03 \%$ \\
Total $^{\text {b }}$ & 87 & 55 & 142 & $100 \%$ & 28 & 5 & 33 & $100 \%$ \\
\hline
\end{tabular}

${ }^{\mathrm{a}}$ Indicates that a student received the highest score on both the motive and strategy subscales

${ }^{\mathrm{b}}$ The total number of students does not coincide with the starting values because one student was undefined

The statistics obtained from the subscales for deep motive, deep strategy, surface motive, and surface strategy are detailed in Table 4. 
Table 4. Statistics for the subscale scores

\begin{tabular}{|c|c|c|c|c|}
\hline \multirow[b]{2}{*}{ Statistic } & \multicolumn{2}{|c|}{ Deep } & \multicolumn{2}{|c|}{ Surface } \\
\hline & Motive & Strategy & Motive & Strategy \\
\hline Minimum & 8 & 7 & 5 & 5 \\
\hline Maximum & 23 & 22 & 25 & 22 \\
\hline Mean & 16.47 & 14.59 & 11.11 & 12.47 \\
\hline Median & 17 & 14 & 11 & 12 \\
\hline Std. Deviation & 2.856 & 2.768 & 3.338 & 3.246 \\
\hline Skewness & -.101 & .247 & 1.182 & .213 \\
\hline $\begin{array}{l}\text { Std. error of } \\
\text { skewness }\end{array}$ & .183 & .183 & .183 & .183 \\
\hline Kurtosis & -.023 & -.029 & 2.519 & -.172 \\
\hline Std. error of kurtosis & .364 & .364 & .364 & .364 \\
\hline Mean of female & 16.87 & 14.72 & 9.97 & 11.38 \\
\hline Mean of male & 16.26 & 14.52 & 11.71 & 13.03 \\
\hline
\end{tabular}

The mean scores among the women in the deep motive approach group $(M=16.87)$ and in deep strategy group $(M=14.72)$ were higher than the corresponding mean scores among the men $(M=16.26, M=14.52)$. The mean scores among the women in the surface motive group $(M=9.97)$ and the surface strategy group $(M=11.38)$ were lower than the mean scores among the men $(M=11.71, M=13.03)$.

\subsection{The Influence of the Dominant Learning Approach on Achievement}

First, the possible influence of the learning approaches (as categorized on the main scale) was analyzed. The Kolmogorov-Smirnov normality test (Table 5) indicates that the grades in educational unit 3 did fulfill the normality assumption ( $p>.05)$, as shown by the Student's t-test. The grades in educational units 1 and 2 did not follow a normal distribution $(p<.05)$ according to the Mann-Whitney non-parametric U-test.

Table 5. Normality test for grades according to the main scale

\begin{tabular}{lcccc}
\hline & & \multicolumn{3}{c}{ Kolmogorov-Smirnov } \\
Score & Approach & Statistic & df & Sig. \\
\hline Educational Unit 1 & Surface & .108 & 25 & $.200^{*}$ \\
& Deep & .101 & 124 & .003 \\
Educational Unit 2 & Surface & .189 & 22 & .039 \\
& Deep & .207 & 117 & .000 \\
Educational Unit 3 & Surface & .129 & 20 & $.200^{*}$ \\
& Deep & .045 & 111 & $.200^{*}$ \\
\hline
\end{tabular}

* This is a lower bound of the true significance

The Student's t-test (Table 6) indicates that there are significant differences between the grades achieved in educational unit 3 by the students with a dominant surface approach $(M=4.12 ; S D=2.199)$ and those with a dominant deep approach $(M=4.98 ; S D=1.656 ; t(129)=-2.041 ; p=.043$; with a small effect, $d=0.359)$. 
Table 6. Student's t-test for educational unit 2 by approach, as measured by the main scale

\begin{tabular}{lcccccc}
\hline & & \multicolumn{2}{c}{ Levene's Test } & \multicolumn{3}{c}{ t-test for Equality of Means } \\
& & F & Sig. & t & df & Sig. (2-tailed) \\
\hline Educational unit 3 & $\begin{array}{c}\text { Equal variance } \\
\text { assumed } \\
\text { Equal variance }\end{array}$ & 1.552 & .215 & -2.041 & 129 & .043 \\
& & & & -1.677 & 23.039 & .107 \\
\hline
\end{tabular}

Nevertheless, the Mann-Whitney U-test (Table 7) indicates that there were no significant differences between the shallow and deep approach scores in educational unit $1(U(N=149)=1274, p=.161)$ and educational unit 2 $(U(N=139)=1227.5, p=.731)$.

Table 7. Mann-Whitney U-test for grades in educational units 1 and 2 by approach, as measured by the main scale

\begin{tabular}{lcccc}
\hline & & \multicolumn{3}{c}{ Test Statistics } \\
& Mann-Whitney U & Wilcoxon W & Z & Asymp. Sig. (2-tailed) \\
\hline Educational unit 1 & 1274.000 & 1599.000 & -1.402 & .161 \\
Educational unit 2 & 1227.500 & 1480.500 & -0.343 & .731 \\
\hline
\end{tabular}

Second, we evaluated the possible influence of learning approaches as measured on the subscales. The Kolmogorov-Smirnov normality test (Table 8) indicates that the grades for educational unit 3 do fulfill the assumption of normality ( $p>.05)$, and an ANOVA was conducted. The grades for educational units 1 and 2 do not follow a normal distribution $(p<.05)$, and the non-parametric Kruskal-Wallis test was used.

Table 8 . Normality test for grades using the subscale approach

\begin{tabular}{|c|c|c|c|c|}
\hline \multirow[b]{2}{*}{ Qualifications } & \multirow[b]{2}{*}{ Approach } & \multicolumn{3}{|c|}{ Kolmogorov-Smirnov } \\
\hline & & Statistic & $\mathrm{df}$ & Sig. \\
\hline \multirow[t]{4}{*}{ Educational unit 1} & Surface Motive (SM) & .164 & 12 & $.200 *$ \\
\hline & Surface Strategy (SS) & .185 & 14 & $.200 *$ \\
\hline & Deep Motive (DM) & .102 & 90 & .023 \\
\hline & Deep Strategy (DS) & .195 & 21 & .036 \\
\hline \multirow[t]{4}{*}{ Educational unit 2} & Surface Motive (SM) & .174 & 10 & $.200 *$ \\
\hline & Surface Strategy (SS) & .218 & 13 & .092 \\
\hline & Deep Motive (DM) & .209 & 84 & .000 \\
\hline & Deep Strategy (DS) & .204 & 19 & .036 \\
\hline \multirow[t]{4}{*}{ Educational unit 3} & Surface Motive (SM) & .169 & 10 & $.200 *$ \\
\hline & Surface Strategy (SS) & .137 & 12 & $.200 *$ \\
\hline & Deep Motive (DM) & .058 & 78 & $.200 *$ \\
\hline & Deep Strategy (DS) & .105 & 19 & $.200^{*}$ \\
\hline
\end{tabular}

* This is a lower bound of the true significance.

The ANOVA test (Table 9) indicates that there are no significant differences in the educational unit 3 grades among the students with each of the four dominant subscale approaches $(F(3,115)=.788, p=.503)$. 
Table 9. ANOVA for educational unit 3 grades by approach, as measured by the subscales

\begin{tabular}{lccccccccccc}
\hline & \multicolumn{2}{c}{ Levene's Test } & \multicolumn{4}{c}{ Snedecor } & \multicolumn{4}{c}{ ANOVA } & \multicolumn{3}{c}{ Welch } \\
& Statistic & Sig. & F & df1 & df2 & Sig. & F & df1 & df2 & Sig. \\
\hline Educational unit 3 & 2.185 & .094 & .788 & 3 & 115 & .503 & .525 & 3 & 23.573 & .669 \\
\hline
\end{tabular}

The Kruskal-Wallis test (Table 10) indicates that there are no significant differences among the groups with the four different approaches in the grades in educational unit $1\left(\chi^{2}(3, N=137)=2.529, p=.470\right)$ and educational unit 2 $\left(\chi^{2}(3, N=126)=1.232, p=.745\right)$.

Table 10. Kruskal-Wallis test for grades in educational units 1 and 2 by approach, as measured by the subscales

\begin{tabular}{lcccc}
\hline & & \multicolumn{3}{c}{ Kruskal-Wallis Test } \\
& $\mathrm{N}$ & Chi-Square & $\mathrm{df}$ & Asymp. Sig. \\
\hline Educational unit 1 & 137 & 2.529 & 3 & .470 \\
Educational unit 2 & 126 & 1.232 & 3 & .745 \\
\hline
\end{tabular}

These tests do not indicate that the dominant approach has an influence on grades, except for the approach measured by the main scale in educational unit 3 .

\subsection{The Relationship between Learning Approach and the Extent of WebCT Use}

Next, we determined whether there are significant differences in the average scores on the main scale as well as on the subscales with respect to the extent of WebCT platform use. To that effect, three levels of platform use were established according to the number of hours the students spent on WebCT:

- Low: between 0 and the $33^{\text {rd }}$ percentile;

- Intermediate: between the $33^{\text {rd }}$ and $67^{\text {th }}$ percentiles;

- High: between the $67^{\text {th }}$ percentile and the maximum number of hours spent on the platform.

The scores obtained for each approach are ordinal because they come from the Likert scale on the R-SPQ-2F questionnaire, and thus, a non-parametric test was used for comparison. In this case, the Kruskal-Wallis test was used because it allows for the three categories of the "extent of platform use."

Table 11 shows the means and the standard deviations of the scores for each learning approach with respect to the extent of platform use, as measured by the number of hours spent on WebCT. 
Table 11. Descriptive statistics for learning approach scores by extent of platform use

\begin{tabular}{llcccc}
\hline \multirow{2}{*}{ Approach } & & \multicolumn{3}{c}{ Descriptive Statistics } & \\
\hline Deep & Degree of employment & N & Mean & Std. Deviation & Mean Rank (MR) \\
& Low intensity & 41 & 29.88 & 4.279 & 75.76 \\
& Medium intensity & 65 & 30.60 & 4.965 & 84.48 \\
Deep Motive & High intensity & 70 & 32.16 & 4.960 & 99.70 \\
& Low intensity & 41 & 16.22 & 2.669 & 81.33 \\
& Medium intensity & 65 & 16.02 & 2.730 & 81.61 \\
Deep Strategy & High intensity & 70 & 17.03 & 3.017 & 99.10 \\
& Low intensity & 41 & 13.66 & 2.585 & 73.16 \\
& Medium intensity & 65 & 14.58 & 2.855 & 87.85 \\
Surface & High intensity & 70 & 15.13 & 2.681 & 98.09 \\
& Low intensity & 41 & 25.24 & 4.928 & 107.60 \\
& Medium intensity & 65 & 24.80 & 5.993 & 99.30 \\
Surface Motive & High intensity & 70 & 21.47 & 5.612 & 67.29 \\
& Low intensity & 41 & 11.88 & 3.002 & 105.04 \\
& Medium intensity & 65 & 11.77 & 3.408 & 97.95 \\
Surface Strategy & High intensity & 70 & 10.06 & 3.221 & 70.04 \\
& Low intensity & 41 & 13.37 & 3.006 & 104.48 \\
& Medium intensity & 65 & 13.03 & 3.221 & 98.17 \\
& High intensity & 70 & 11.41 & 3.155 & 70.16 \\
\hline
\end{tabular}

The Kruskal-Wallis test (Table 12) indicates that significant differences were found in the standard deviations of low, intermediate, and high levels of platform use in the deep approach group (MR=75.76, MR=84.48, $\left.\mathrm{MR}=99.70 ; \chi^{2}(2, N=176)=6.391, p=.041\right)$, in the deep strategy group $\left(\mathrm{MR}=73.16, \mathrm{MR}=87.85, \mathrm{MR}=98,09 ; \chi^{2}(2\right.$, $N=176)=6.288, p=.043)$, in the surface group $\left(\mathrm{MR}=107.60, \mathrm{MR}=99.30, \mathrm{MR}=67.29 ; \chi^{2}(2, N=176)=20.895\right.$, $p=.000)$, in the surface motive group $\left(\mathrm{MR}=105.04, \mathrm{MR}=97.95, \mathrm{MR}=70.04 ; \chi^{2}(2, N=176)=15.946, p=.000\right)$, and in the surface strategy group $\left(\mathrm{MR}=104.48, \mathrm{MR}=98.17, \mathrm{MR}=70.16 ; \chi^{2}(2, N=176)=15.583, p=.000\right)$. No significant differences were found in the deep motive approach group $\left(\chi^{2}(2, N=176)=5.095, p=.078\right)$.

Table 12. Kruskal-Wallis test for the approach scores by extent of platform use

\begin{tabular}{lcccc}
\hline & & \multicolumn{3}{c}{ Kruskal-Wallis Test } \\
Approach & $\mathrm{N}$ & Chi-Square & $\mathrm{df}$ & Asymp. Sig. \\
\hline Deep & 176 & 6.391 & 2 & .041 \\
Deep Motive & 176 & 5.095 & 2 & .078 \\
Deep Strategy & 176 & 6.288 & 2 & .043 \\
Surface & 176 & 20.895 & 2 & .000 \\
Surface Motive & 176 & 15.946 & 2 & .000 \\
Surface Strategy & 176 & 15.583 & 2 & .000 \\
\hline
\end{tabular}

The tests confirm the influence of the dominant approach on the extent of WebCT platform use, except in the case of the scores found in the deep motive group.

3.4 The Influence of the Dominant Learning Approach on the Assessment of WebCT

A Likert scale was used on the PSEW questionnaire that was used to determine the students' perceptions of the 
course, and the variable was ordinal; thus, non-parametric tests were needed. Based on the main scale, there are two possible values for the dominant learning approach, and therefore, the Mann-Whitney U-test was used to analyze the possible influence of the main scale categories on the assessments of WebCT. Based on the subscale, there are four possible values for the dominant learning approach, and therefore, the Kruskal-Wallis test was used to determine the possible influence of the subscale categories.

Table 13 shows the means and standard deviations of the overall assessments of WebCT by the students according to the dominant learning approach as measured by the main scale as well as the subscales.

Table 13. Descriptive statistics for the assessments of the WebCT platform by dominant learning approach

\begin{tabular}{lcccc}
\hline & \multicolumn{3}{c}{ Descriptive Statistics } \\
Dominant approach & $\mathrm{N}$ & Mean & Std. Deviation & Mean Rank (MR) \\
\hline Deep & 97 & 4.3341 & .42659 & 59.05 \\
Deep Motive & 67 & 4.3334 & .37617 & 53.38 \\
Deep Strategy & 18 & 4.3767 & .49849 & 60.22 \\
Surface & 15 & 4.0900 & .42472 & 40.03 \\
Surface Motive & 7 & 4.1286 & .48347 & 41.79 \\
Surface Strategy & 10 & 4.0230 & .37184 & 30.00 \\
\hline
\end{tabular}

The Mann-Whitney U-test (Table 14) indicates that significant differences were found in the overall assessments of the WebCT platform between the students with a deep approach $(\mathrm{MR}=59.05)$ and the students with a surface approach $(\mathrm{MR}=40.03, U(N=102)=480.5, p=.034)$.

Table 14. Mann-Whitney U-test for the assessments of the WebCT platform by dominant learning approach, as measured by the main scale

\begin{tabular}{cccc}
\hline & \multicolumn{2}{c}{ Test Statistics } & \\
Mann-Whitney U & Wilcoxon W & Z & Asymp. Sig. (2-tailed) \\
\hline 480.500 & 600.500 & -2.118 & .034 \\
\hline
\end{tabular}

The Krustkal-Wallis test indicates (Table 15) significant differences in the overall assessments of the WebCT platform among the students with a deep motive approach $(\mathrm{MR}=53.38)$, a deep strategy approach $(\mathrm{MR}=60.22)$, a surface motive approach $(\mathrm{MR}=41.79)$ and a surface strategy approach $\left(\mathrm{MR}=30.00, \chi^{2}(3, N=102)=7.925\right.$, $p=.048)$.

Table 15. Kruskal-Wallis Test for the Assessments of the WebCT Platform by Dominant Learning Approach, as Measured by the Subscales

\begin{tabular}{cccc} 
& & \multicolumn{2}{c}{ Kruskal-Wallis Test } \\
$\mathrm{N}$ & Chi-Square & df & Asymp. Sig. \\
\hline 102 & 7.925 & 3 & .048 \\
\hline
\end{tabular}

The tests confirm the influence of the dominant learning approach on WebCT platform assessments.

\section{Discussion and Conclusions}

Overall, the students have a deep learning approach with a low level of intensity, which coincides with earlier research in engineering education (Vázquez-Martínez, 2011; Esquivel, Rodríguez \& Padilla, 2009; Muñoz \& Gómez, 2005), although other researchers in the same field have produced conflicting evidence (Gynnild \& Myrhaug, 2012; Nelson, Shoup \& Kuh, 2005; Buendía \& Olmedo, 2002). These researchers indicate that the shallow learning approach predominates in these degree programs. Kember, Jamieson, Pomfret and Wong (1995) 
suggest that the tendency to use a shallow approach could be due to the fact that the students must complete numerous short, well-defined assignments, which is not the case for the students in this study.

It is noteworthy that the deep learning approach is found more frequently among the female students according to both subscales. This result differs from other studies conducted in engineering (Hernández, Rodríguez, Ruiz \& Esquivel, 2010; Buendía \& Olmedo, 2002).

Except for the grades achieved in educational unit 3, for which significant differences were found with respect to the dominant approach as measured by the main scale, learning approaches (measured by the main scale and the subscales) had no influence on the grades achieved in other units. Therefore, it can be concluded that in our study, the dominant learning approach did not affect achievement, a finding that coincides with other studies (Vázquez-Martínez, 2011; Yilmaz \& Orhan, 2010; Ellis, Goodyear, Prosser \& O’Hara, 2006; Hannafin, Oliver, Hill, Glazer \& Sharma, 2003). This result suggests that the blended learning methodology and the course management procedures had a positive influence on all of the students regardless of their learning approach. In future studies, the circumstances that produced the significant differences in the grades in educational unit 3 should be studied.

The students who used the platform the least had the highest average scores for the surface approach (both on the main scale and the subscales) and the lowest scores for the deep approach overall, deep motive, and deep strategy. By contrast, the students who used the platform more obtained the lowest scores for the surface approach overall, surface motive, and surface strategy, and the highest scores for the deep approach overall, deep motive, and deep strategy. In both cases, the differences were significant, which allows us to conclude that the students with the highest scores on the surface scale (both the main scale and the subscales) are those who are least likely to use the technological tools that have been offered to them to improve the learning process. Likewise, the students with the highest deep approach scores are those who make the best use of these tools.

Finally, the significant differences in the students' assessments of the WebCT platform according to their dominant learning approach allow us to conclude that students' learning approaches influence their assessments of technological tools. The students who have a dominant deep learning approach (according to both the main scale and the subscales) valued the platform most highly and used it most. This result coincides with other research studies (Ginns \& Ellis, 2007; Lizzio, Wilson, \& Simons, 2002). Various authors (Watkins, 1983; Ginns \& Ellis, 2007; Webster, Chan, Prosser \& Watkins, 2009) have suggested that when students have positive perceptions of the learning environment, they tend to use a deeper learning approach and demonstrate higher academic achievement. It should be noted that the blended learning model should include a significant amount of independent work, and students' success depends on their self-management skills and their positive perceptions of the learning environment (Reisetter, Lapointe \& Korcuska, 2007). Therefore, it is increasingly important to understand how each student learns to better direct his or her individual learning process, especially in an area like engineering. The support that students receive from the teacher is key. Students must also perceive that teachers have an interest in developing attractive learning environments where each student learns according to his or her own needs and characteristics.

It is important that the students enage in deep learning. To achieve this, it is necessary to develop activities in which the students must establish relationships between new and previous knowledge, use different sources of information and look for applications in everyday life. Students should aim to achieve understanding rather than memorization and should seek to develop learning strategies based on reflection. Additionally, assessment strategies that promote memorization should be abandoned in favor of those that require the student to demonstrate an understanding of the content and the ability to interrelate it. To achieve these goals, Biggs (2005) makes the following recommendations: explicitly presenting the structure of the topic or the subject, teaching to obtain a positive response from the students, building on students' previous knowledge, questioning and eradicating students' erroneous conceptions, evaluating the structure instead of independent data, teaching and assessing to stimulate a positive work atmosphere in which students can learn from their errors and using teaching and assessment methods that support the explicit goals and objectives of the course.

In short, the objective is to develop a constructive alignment system (Biggs, 2003). Such a system creates a learning environment that supports learning activities (alignment) that allow students to construct meaning (constructivism).

With the objective of promoting deep learning, Information and Communication Technologies seem to effectively increase students' understanding of course content and improve motivation (Carrascal et al., 2009; Ricci \& Stessi, 2009; Vázquez-Martínez, 2011). However, pedagogical aspects are of greater importance than technical ones, and students should be provided with, among other tools, a valuable and large set of resources 
that they can interact with to construct their knowledge; assessment tools to test their learning level; activities that integrate content already studied and acquired knowledge with new knowledge and that require students to develop reflection processes; and communication tools that promote the social construction of knowledge.

\section{References}

Akyol, Z., \& Garrison, R. (2011). Understanding cognitive presence in an online and blended community of inquiry: Assessing outcomes and processes for deep approaches to learning. British Journal of Educational Technology, 42(2), 233-250. http://dx.doi.org/10.1111/j.1467-8535.2009.01029.x

Arbaugh, J. B. (2004). Learning to learn online: A study of perceptual changes between multiple online course experiences. Internet and Higher Education, 7, 169-182. http://dx.doi.org/10.1016/j.iheduc.2004.06.001

Bassett, P. (2011). How do students view asynchronous online discussions as a learning experience? Interdisciplinary Journal of e-Learning and Learning Objects, 7, 69-79.

Bersin, A. W. (2004). The Blended Learning Book. Best practices, proven methologies and lessons learned. San Francisco: Pfeiffer.

Biggs, J. B. (1987). Student approaches to learning and studying. Hawthorn, Vic.: Australian Council for Educational Research.

Biggs, J. B. (2003). Teaching for quality learning at university (2nd ed.). Buckingham: Society for Research into Higher Education \& Open University Press.

Biggs, J. B. (2005). Aligning teaching for constructing learning. Retrieved from http://www.heacademy.ac.uk/embedded_object.asp?id=21686\&filename=Biggs

Biggs, J. B., Kember, D., \& Leung, D. (2001). The revised two-factor Study Process Questionnaire: R-SPQ-2F. British Journal of Educational Psychology, 71(1), 133-149. http://dx.doi.org/10.1348/000709901158433

Boekaerts, M. (1996). Personality and the psychology of learning. European Journal of Personality, 10(5), 377-404. http://dx.doi.org/10.1002/(SICI)1099-0984(199612)10:5<377::AID-PER261>3.0.CO;2-N

Buendía, L., \& Olmedo, E. (2002). El género: ¿constructor mediador en los enfoques de aprendizaje universitario. RIE, 20(2), 511-524.

Carrascal, N., Alvarino, G., \& Díaz, E. (2009). Estrategias mediadas por TIC para el desarrollo de enfoque de aprendizaje profundo en estudiantes universitarios. FOLIOS, 29, 3-18.

Cheng, K. H., \& Tsai, C. C. (2012). Students' interpersonal perspectives on, conceptions of and approaches to learning in online peer assessment. AJET, 28(4), 599-618. Retrieved from http://www.ascilite.org.au/ajet/ajet28/cheng-kh.html

Ching, Y. H., \& Hsu, Y. C. (2011). Design-grounded assessment: A framework and a case study of Web 2.0 practices in higher education. AJET, 27(5), 781-797.

Cooner, T. S. (2010). Creating opportunities for students in large cohorts to reflect in and on practice: Lessons learnt from a formative evaluation of students' experiences of a technology enhanced blended learning design. British Journal of Educational Technology, 41(2), 271-286. http://dx.doi.org/10.1111/j.1467-8535.2009.00933.x

Davidson, L. K. (2011). A 3-year experience implementing blended TBL: Active instructional methods can shift $\begin{array}{lllll}\text { student attitudes to learning. Medical Teacher, 33(9), } & \text { 750-753. }\end{array}$ http://dx.doi.org/10.3109/0142159X.2011.558948

De Witt, C., \& Kerres, M. (2003). A didactical framework for the design of blended learning arrangements, Journal of Educational Media, 28(2-3), 101-113. http://dx.doi.org/10.1080/1358165032000165653

Diseth, A. (2007). Students' evaluations of teaching, approaches to learning, and academic achievement. Scandinavian Journal of Educational Research, 51(2), 185-204. http://dx.doi.org/10.1080/00313830701191654

Driscoll, M. (2002). Web-based training. San Francisco: Jossey-Bass/Pfeiffer.

Duff, A., Boyle, E., Dunleavy, K., \& Ferguson, J. (2004). The relationship between personality, approach to learning and academic performance. Personality and Individual Differences, 36, 1907-1920. http://dx.doi.org/10.1016/j.paid.2003.08.020

Ellis, R. A., Ginns, P., \& Piggott, L. (2009). E-learning in higher education: Some key aspects and their 
relationship to approaches to study. Higher Education Research and Development, 28, 303-318. http://dx.doi.org/10.1080/07294360902839909

Ellis, R. A., Goodyear, P., Brillant, M., \& Prosser, M. (2008). Student experiences of problem-based learning in pharmacy: conceptions of learning, approaches to learning and the integration of face-to-face and on-line activities. Advances in Health Sciences Education, 13(5), 675-692. http://dx.doi.org/10.1007/s10459-007-9073-3

Ellis, R. A., Goodyear, P., Calvo, R. A., \& Prosser, M. (2008). Engineering students' conceptions of and approaches to learning through discussions in face-to-face and online contexts. Learning and Instruction, 18(3), 267-282. http://dx.doi.org/10.1016/j.learninstruc.2007.06.001

Ellis, R. A., Goodyear, P., Prosser, M., \& O'Hara. (2006). How and what university students learn through online and face-to-face discussions: Conceptions, intentions and approaches. Journal of Computer Assisted Learning, 22(4), 244-256. http://dx.doi.org/10.1111/j.1365-2729.2006.00173.x

Ellis, R. A., Taylor, C. E., \& Drury, H. (2007). Learning science through writing: Associations with prior conceptions of writing and perceptions of a writing program. Higher Education Research and Development, 26(3), 297-311. http://dx.doi.org/10.1080/07294360701494310

Entwistle, N. J. (1988), Styles of learning and teaching. An integrated outline of educational psychology for students, teachers and lecturers. London: David Fulton publishers.

Entwistle, N. J. (2005). Contrasting perspectives on learning. In F. Marton, D. Hounsell, \& N. Entwistle (Eds.), The Experience of Learning: Implications for teaching and studying in higher education (pp. 3-21). Edinburgh: University of Edinburgh, Centre for Teaching, Learning and Assessment.

Esquivel, J., Rodríguez, M. C., \& Padilla, V. M. (2009). Enfoques hacia el aprendizaje, motivos y estrategias de estudiantes de las carreras de enfermería, ingeniería y organización deportiva. Revista de Pedagogía, 30(87), 309-331.

French, B. F., Immekus, J. C., \& Oakes, W. C. (2005). An examination of indicators of engineering students' success and persistence. Journal of Engineering Education, 94(4), 419-425. http://dx.doi.org/10.1002/j.2168-9830.2005.tb00869.x

Garrison, D. R., \& Vaughan, N. D. (2008). Blended learning in higher education-Framework, principles and guidelines. CA: Jossey-Bass - A Wiley Imprint.

Garrison, D. R., Anderson, T., \& Archer, W. (2000). Critical inquiry in a text-based environment: Computer conferencing in higher education. The Internet and Higher Education, 2, 87-105. http://dx.doi.org/10.1016/S1096-7516(00)00016-6

George, D., \& Mallery, P. (1995). SPSS/PC+ step by step: A simple guide and reference. Belmont: Wadsworth Publishing Company.

Ginns, P., \& Ellis, R. A. (2009). Evaluating the quality of e-learning at the degree level in the student experience of blended learning. British Journal of Educational Technology, 40(4), 652-663. http://dx.doi.org/10.1111/j.1467-8535.2008.00861.x

Ginns, P., \& Ellis, R.A. (2007). Quality in blended learning: Exploring the relationships between on-line and face-to-face teaching and learning. Internet and Higher Education, 10, 53-65. http://dx.doi.org/10.1016/j.iheduc.2006.10.003

Godfrey, E., Aubrey, T., \& King, R. (2010). Who leaves and who stays? Retention and attrition in engineering education. Journal of Engineering Education, 5(2), 26-40. http://dx.doi.org/10.11120/ened.2010.05020026

Gynnild, V., \& Myrhaug, D. (2012). Revisiting approaches to learning in science and engineering: A case study. European Journal of Engineering Education, 37(5), 458-470. http://dx.doi.org/10.1080/03043797.2012.709483

Halawi, L., McCarthy, R., \& Moughalu, N. (2009). Student approaches to learning: An exploratory study. Issues in Information Systems, 10(1), 13-21.

Hall, M., Ramsay, A., \& Raven, J. (2004). Changing the learning environment to promote deep learning approaches in first-year accounting students. Accounting Education, 13(4), 489-505. http://dx.doi.org/10.1080/0963928042000306837

Hannafin, M., Oliver, K., Hill, J., Glazer, E., \& Sharma, P. (2003). Cognitive and learning factors in web-based 
distance learning environments. In M. Moore, \& W. Anderson (Eds.), Handbook of distance education (pp. 245-272). Mahwah, NJ: Lawrence Erlbaum.

Harding, A., Kaczynski, D., \& Wood, L. (2005). Evaluation of blended learning: Analysis of qualitative data. Retrieved from http://ojs-prod.library.usyd.edu.au/index.php/IISME/article/viewFile/6436/7085

Heinström, J. (2006). Fast surfing for availability or deep diving into quality motivation and information seeking among middle and high school students. Information Research, 11(4). Retrieved from http://InformationR.net/ir/11-4/paper265.html

Heinze, A., \& Procter, C. (2006). Online communication and information technology education. Journal of Information Technology Education, 5, 235-249.

Hernández, F., Rodríguez, M. C., Ruiz, E., \& Esquivel, J. E. (2010). Enfoques de aprendizaje en alumnos universitarios de la titulación de ciencias de la Actividad Física y del Deporte de España y México. Revista Iberoamericana de Educación, 53(7), 1-11.

Heterick, B., \& Twigs, G. (2003). The learning Make Space. Retrieved from http://www.center.rpi.edu/LFORUMILM/Feb03.html

Kember, D., \& Harper, G. (1987). Approaches to studying research and their implications for the quality of learning from distance education. Journal of Distance Education, 2(2), 15-30.

Kember, D., Jamieson, Q. W., Pomfret, M., \& Wong, E. T. T. (1995). Learning approaches study time and academic performance. Higher Education, 29, 329-343. http://dx.doi.org/10.1007/BF01384497

Kemp, J. E., Morrison, G. R., \& Ross, S. M. (1998). Designing Effective Instruction (2nd ed.). Upper Saddle River, NJ: Prentice Hall.

Klein, H. J., Noe, R. A, \& Wang, C. (2006). Motivation to Learn and Course Outcomes: The Impact of Delivery Mode, Learning Goal Orientation, and Perceived Barriers and Enablers. Personnel Psychology, 59, 665-702. http://dx.doi.org/10.1111/j.1744-6570.2006.00050.x

Laird, T., Shoup, R., \& Kuh, G. (2005, May). Measuring deep approaches to learning using the national survey of student engagement. Chicago: Annual Meeting of the Association for Institutional Research.

Lashley, C., \& Barron, P. (2006). The learning style preferences of hospitality and tourism students: Observations from an international and cross-cultural study. International Journal of hospitality and Management, 25(4), 552-569. http://dx.doi.org/10.1016/j.ijhm.2005.03.006

Lingard, J., Minasian-Batmanian, L., Vella, G., Cathers, I., \& Gonzalez, C. (2009). Do students with well-aligned perceptions of question difficulty perform better? Assessment \& Evaluation in Higher Education, 34, 603-619. http://dx.doi.org/10.1080/02602930802287249

Lizzio, A., Wilson, K., \& Simons, R. (2002). University students' perceptions of the learning environment and academic outcomes: Implications for theory and practice. Studies in Higher Education, 27, $27-51$. http://dx.doi.org/10.1080/03075070120099359

Lucas, U. (2001). Deep and surface approaches to learning within introductory accounting: A phenomenographic study. Accounting Education, 10(2), 161-184. http://dx.doi.org/10.1080/09639280110073443

MacGregor, C. J. (2001). A comparison of student perceptions in traditional and online classes. Academic Exchange Quarterly, 5(4), 143-148.

MacKenzie, N., \& Walsh, A. (2009). Enhancing the curriculum: Shareable multimedia learning objects. Journal of Systems and Information Technology, 11, 71-83. http://dx.doi.org/10.1108/13287260910932421

Marton, F., \& Säljo, R. (1976). On qualitative differences in learning: Outcome and process. British Journal of Educational Psychology, 46, 3-11.

Marton, F., \& Saljo, R. (2005). Approaches to learning. In F. Marton, D. Hounsell, \& N. J. Entwistle (Eds.), The experience of learning: implications for teaching and studying in higher education (pp. 39-58). Edinburgh: University of Edinburgh, Centre for Teaching, Learning and Assessment.

Meurant, R. C. (2010). How computer-based internet-hosted learning management systems such as Moodle can help develop L2 digital literacy. International Journal of Multimedia and Ubiquitous Engineering, 5(2), 1-7.

Mitchell, P., \& Forer, P. (2010). Blended learning: The perceptions of first-year geography students. Journal of Geography in Higher Education, 34(1), 77-89. http://dx.doi.org/10.1080/03098260902982484 
Mosca, J. B., Ball, D. R., Buzza, J. S., \& Paul, D. P. (2010). A Comprehensive Student-based Analysis of Hybrid Courses: Student Preferences and Design Criteria for Success. Journal of Business and Economics Research, 3(5), 7-21.

Muñoz, E., \& Gómez, J. (2005). Enfoques de aprendizaje y rendimiento académico de los estudiantes universitarios. RIE, 23(2), 417-432.

Nelson, T., Shoup, R., \& Kuh, G. (2005). Deep learning and college outcomes: Do fields of study differ? Paper presented at the Annual Meeting of the Association for Institutional Research, May-June. San Diego.

Neto, P., Vieira, A., Moreira, B., \& Ribeiro, L. M. (2013). Blended-learning approach in caad: architectural representation and communication focused in teaching architecture and art. International Conference Interactive Collaborative Learning. Retrieved from http://repositorio-aberto.up.pt/handle/10216/64745

Neumann, D., Neumann, M., \& Hood, M. (2011). Evaluating computerbased simulations, multimedia and animations that help integrate blended learning with lectures in first year statistics. AJET, 27(2), 274-289.

Osguthorpe, R. T., \& Graham, C. R. (2003). Blended learning environments. Quarterly Review of Distance Education, 4(3), 227-233.

Oskay, E., Akkoyunlu, B., \& Yilmaz, A. (2010). Prospective chemistry teachers' learning styles and learning $\begin{array}{lllll}\text { preferences. Procedia Social and Behavioral Sciences, 2, 1362-1367. } & \text {. }\end{array}$ http://dx.doi.org/10.1016/j.sbspro.2010.03.201

Palloff, R., \& Pratt, K. (1999). Buiding learning communities in cyberspace. San Fracisco: Joseey-Bass Publishers.

Precel, K., Esthet-Alkalai, Y., \& Alberton, Y. (2009). Pedagogical and design aspects of a blended learning course. International Review of Research in Open and Distance Learning, 10(2), 1-16.

Prosser, M., \& Trigwell, K. (1999). Relational perspectives on higher education teaching and learning in the science. Studies in Science Education, 33(1), 31-60. http://dx.doi.org/10.1080/03057269908560135

Prosser, M., Walker, P., \& Millar, R. (1996). Differences in students' perceptions of learning physics. Physics Education, 31(1), 43-48. http://dx.doi.org/10.1088/0031-9120/31/1/022

Ramsden, P. (2002). Learning to teach in higher education. London: Routledge.

Ramsden, P., Martin, E., \& Bowden, J. (1989). School environment and sixth form pupils' approaches to learning. $\begin{array}{lllll}\text { British Journal of } & \text { Educational }\end{array}$ http://dx.doi.org/10.1111/j.2044-8279.1989.tb03086.x

Recio, M. A. (2007). Enfoques de aprendizaje y desempeño en alumnos de educación a distancia. Sevilla: Universidad de Sevilla.

Reisetter, M., Lapointe, L., \& Korcuska, J. (2007). The impact of altered realties: Implications of online delivery for learners' interactions, expectations, and learning skills. International Journal on E- Learning, 6(1), $55-80$.

Ricci, M. B., \& Stassi, H. M. (2009). Aplicación de enfoques de aprendizaje en entornos virtuales. X Encuentro Internacional Virtual Educa. Buenos Aires - Argentina.

Sabry, K., \& Baldwin, L. (2003). Web-based learning interaction and learning styles. British Journal of Educational Technology, 34, 443-454. http://dx.doi.org/10.1111/1467-8535.00341

Scott, C. (2010). The enduring appeal of Learning styles. Australian journal of Education, 54(1), 5-17. http://dx.doi.org/10.1177/000494411005400102

Scouller, K. (1998). The influence of assessment method on students' learning approaches: Multiple choice question examination versus assignment essay. Higher Education, 35, 453-472. http://dx.doi.org/10.1023/A:1003196224280

Shannon, S. J., Francis, R. L., Leng Chooi, Y., \& Lynn Ng, S. (2012). Approaches to the use of blended learning in teaching tectonics of design to architecture/design and architectural engineering students. Architectural Science Review, 1-10.

Spencer, K. (2003). Approaches to learning and contemporary accounting education. Education in a changing environment. Retrieved from http://www.ece.salford.ac.uk/proceedings/papers/ks_03.rtf

Stricker, D., Weible, D., \& Bissmath, B. (2011). Efficient Learning using a Virtual Learning Environment in a 
University Class. Computers \& $\quad$ Cducation, $\quad 56(2), \quad$ 495-504. http://dx.doi.org/10.1016/j.compedu.2010.09.012

Svensson, L. (1977). On qualitative differences in learning III: Study skill and learning. British Journal of Educational Psychology, 47(3), 233-243. http://dx.doi.org/10.1111/j.2044-8279.1977.tb02352.x

Trigwell, K., \& Ashwin, P. (2006). An exploratory study of situated conceptions of learning and learning environments. Higher Education, 51(2), 243-258. http://dx.doi.org/10.1007/s10734-004-6387-4

Vázquez-Martínez, A. I. (2011). Relación entre los enfoques de aprendizaje y el desempeño de los estudiantes en la enseñanza presencial apoyada por plataforma educativa. Estudio de la percepción de los estudiantes. Sevilla: Universidad de Sevilla.

Vázquez-Martínez, A. I., \& Alducin-Ochoa, J. M. (2008, June). Mejora del resultado académico a través de entrenamiento en la plataforma educativa WebCT. Paper presented at the $V$ Jornadas de Redes de Investigación en docencia universitaria. Universidad de Alicante: Spain.

Watkins, D. (1983). Depth of processing and the quality of learning outcomes. Instructional Science, 12, 49-58.

Webster, B. J., Chan, W. S. C., Prosser, M. T., \& Watkins, D. A. (2009). Undergraduates' learning experience and learning process: quantitative evidence from the East. Higher Education, 58(3), 375-386.

Yilmaz, M. B., \& Orhan, F. (2010). Pre-service English teachers in a blended learning environment with respect to their learning approaches. TOJET, 9(1), 157-164.

\section{Copyrights}

Copyright for this article is retained by the author(s), with first publication rights granted to the journal.

This is an open-access article distributed under the terms and conditions of the Creative Commons Attribution license (http://creativecommons.org/licenses/by/3.0/). 